\title{
Herbivory Effects on Ephedra spp. in the Chihuahuan Desert
}

\author{
Walter G. Whitford ${ }^{*}$, Yosef Steinberger ${ }^{2 * \#}$ \\ ${ }^{1}$ USDA-ARS Jornada Experimental Range, New Mexico State University, Las Cruces, New Mexico, USA \\ ${ }^{2}$ The Mina and Everard Goodman Faculty of Life Sciences, Bar-Ilan University, Ramat Gan, Israel \\ Email: "Yosef.Steinberger@biu.ac.il
}

How to cite this paper: Whitford, W.G. and Steinberger, Y. (2020) Herbivory Effects on Ephedra spp. in the Chihuahuan Desert. Open Journal of Ecology, 10, 37-44. https://doi.org/10.4236/oje.2020.102003

Received: January 10, 2020

Accepted: February 14, 2020

Published: February 17, 2020

Copyright (C) 2020 by author(s) and Scientific Research Publishing Inc. This work is licensed under the Creative Commons Attribution International License (CC BY 4.0).

http://creativecommons.org/licenses/by/4.0/ (c) (i) Open Access

\begin{abstract}
Two species of Ephedra: E. trifurca and E. torreyana inhabit shrub and grassland habitats in the northern Chihuahuan Desert. E. torreyana is limited to black grama grasslands where grasses are taller than the shrub. E. torreyana is heavily browsed by vertebrates and $E$. trifurca is browsed during some years. We established an experiment with cylindrical exclosures that excluded rabbits and rodents, rabbits but accessible to rodents, for comparison with $E$. torreyana plants available to all herbivores. Plants accessible to all vertebrate herbivores were significantly smaller with shorter stem lengths than plants in exclosures. We concluded that E. torreyana in black grama grassland are largely hidden from vertebrate herbivores and that intense herbivory reflects the degraded state of the study site which makes the E. torreyana evergreen shrubs apparent to vertebrates.
\end{abstract}

\section{Keywords}

Ephedra torreyana, Ephedra trifurca, Exclosures, Jackrabbits

(Lepus californicus), Desert Cottontail Rabbits (Sylvilagus auduboni),

Desertification

\section{Introduction}

The genus Ephedra (Grymnospermae; Gnetales, Ephedraceae) is composed of approximately 50 species in arid and semiarid ecosystems worldwide [1]. Two species (Ephedra trifurca and E. torreyana), which are common in the northern Chihuahuan Desert of the USA, produce dry winged cone bracts and the seeds are wind dispersed. Other Ephedra species that occur in North America are animal dispersed. E. antisyphilitica with succulent, brightly colored cone bracts are *These authors contributed equally to this work. 
dispersed by frugivorous birds and those with small, dry cone bracts and large seeds are dispersed by granivorous rodents (e.g., E. viridis and E. californica) [1]. The Ephedra species in the northern Chihuahuan Desert developed from two pairs of sister species distributed in southwestern North America: E. californica-E. trifurca and E. torreyana-E. viridis and probably occurred in the Late Miocene to Pliocene [2]. They concluded that genetic and climatic changes documented for these regions related to the expansion of arid lands, contributed to the diversification in North American Ephedra, rather than adaptations to new climatic conditions.

The species of Ephedra in the Chihuahuan Desert have very different distribution patterns. E. torreyana is limited to the Chihuahuan Desert and to the cold or cool deserts of Colorado, Arizona, and Nevada. E. trifurca is a plant of the hot deserts occurring in Baja California, the Sonoran and Chihuahuan Deserts. The presence of $E$. torreyana in the northern Chihuahuan Desert may be attributable to the higher elevation of this hot desert $(>1000 \mathrm{~m})$.

There are two species of Ephedra in the northern Chihuahuan Desert: Ephedra torreyana and Ephedra trifurca. Ephedra trifurca is widespread and occupies a variety of habitats and soil types. Ephedra torreyana appears to be limited to black grama (Bouteloua eriopoda) grasslands on loamy soils. E. torreyana does not occur in all B. eriopoda grasslands. We did not find E. torreyana in B. eriopoda grasslands in shallow (depth to cemented calcium carbonate layer $<1 \mathrm{~m}$ ) sandy soils. E. trifurca is a large gymnosperm (at maturity it reaches over $1 \mathrm{~m}$ in diameter and $>1 \mathrm{~m}$ height). E. torreyana is a small plant at maturity $(<0.5 \mathrm{~m}$ diameter and $<0.5 \mathrm{~m}$ height) and is relatively inconspicuous in healthy $B$. eriopoda grasslands. Because most of the grasslands of the rangelands in the Chihuahuan Desert have been replaced by woody shrubs, there are only remnant populations of E. torreyana in shrub-dominated areas. Replacement of grasslands by shrub-dominated ecosystems is a major problem worldwide and has a long history in drylands worldwide [3]. E. torreyana in shrub-dominated communities had been continuously browsed by herbivores since the early 1900's. Surviving plants had few leaves, and the remaining leaves averaged less than 4 $\mathrm{cm}$ in length. These plants were essentially reduced to the dark woody stems, exposed root crown, and surviving small leaves. In a livestock enclosure (bison exclosure with a 4-strand barbed wire fence) around the grassland, the average leaf length of E. torreyana was $18.4 \pm 7.4 \mathrm{~cm}$ [4]. In this black grama grassland we identified three potential vertebrate species that were able to access the interior of the exclosure: the pronghorn (Antilocapra americana), the black-tailed jackrabbit (Lepus californicus) and the desert cottontail (Sylvilagus auduboni). A small number of $E$. torreyana shrubs in the burned area exhibited evidence of browsing (fecal pellets at the base of the plant) and smaller plant canopies than the unbrowsed shrubs. E. torreyana in the burned area were eaten by jackrabbits and/or cottontails in the cool dry season, probably to obtain the water content of the evergreen, succulent leaves. 


\section{Methods}

The study was conducted on the Jornada site on the New Mexico State University Ranch, $40 \mathrm{~km}$ NNE of Las Cruces, Dona Ana County, New Mexico. The Jornada Site is a desert watershed varying in elevation from c. $2000 \mathrm{~m}$ to c. 1000 $\mathrm{m}$ (asl). The 100-year annual rainfall average \pm 1 standard deviation at the New Mexico State University Station, Las Cruces, New Mexico, is $211 \pm 77 \mathrm{~mm}$ [3], with most of that rainfall occurring during late summer from convectional storms. Summer maximum temperatures reached $40^{\circ} \mathrm{C}$ and freezing temperatures are recorded from October through mid-April (data from the Jornada Site Weather Station). All the data obtained in the study were subjected to statisctical analysis of variance using the SAS model of variance (ANOVA and Pearson correlation coefficient). Differences at the $\mathrm{P}<0.05$ level were considered to be significant.

Of the three populations of E. torreyana on the Jornada Experimental Range that we were able to locate, two were low density populations with between 5 and 10 plants per hectare. These populations were located in mesquite coppice dunes (nebkhas) and in a mesquite flatland on sandy loam soil. In the dune area, the E. torreyana were in the bare areas between dunes and the low density may be the result of aeolian sand burying the small shrubs under the dunes. We decided to try to answer the question by working in an area now dominated by tarbush (Flourensia cernua), where the density of E. torreyana was more than 50 plants per hectare. This is an area that was black grama grassland in the past and that receives run-off water from the upper slopes [5]. Since the early 1900's, the site experienced some reduction in run-off water from the higher slopes because of an elevated road with large borrow ditches that is perpendicular to the low slope area. The road and ditches disrupt overland flow which reduces the amount of water reaching the E. torreyana plants. However, the study site is at the terminus of the drainage and the low point on the watershed where it receives drainage from the roadway and nearly $1 \mathrm{~km}$ of tarbush dominated watershed that is higher than the experimental site.

The experiment was set up in October 1999 after the summer monsoon rains and re-measured in January 2001. Another set of measurements was performed in October 2008 after the Jornada Experimental Range removed most of the livestock and the pasture with the E. torreyana experiment was no longer grazed by cattle.

We used cylindrical exclosures of $1.0 \mathrm{~m}$ diameter and $1.5 \mathrm{~m}$ height. These exclosures were used in a study of rodent gramnivory [6]. The rabbit (lagomorph)-rodent exclosures were constructed of hardware cloth with sheet metal at the base and top to prevent rodents from climbing into the cylinder. The rabbit only exclosures were constructed of chicken mesh $(4 \times 2.5 \mathrm{~cm}$ openings with four $9.5 \times 4.5 \mathrm{~cm}$ openings cut out of the base to allow rodents to enter the cylinder and access the plant. Thirty-three plants were randomly assigned to 1) 
rodent-lagomorph exclosure, 2) lagomorph exclosure, and 3) no exclosure-available to all herbivores. The exclosures were sealed to the soil surface with re-bar pegs. Each treatment consisted of 11 plants. When the experiment was set up, we measured two diameters on each plant and its average height. $E$. torreyana plants exposed to all herbivores were identified by flags placed near the plants. The data were subjected to analysis of variance.

\section{Results}

Large differences in precipitation, both annual and monsoon (July-September), occurred in the years when the experiment was set up and in subsequent years. In 1999 when the experiment was set up, the annual precipitation at the site was $150.4 \mathrm{~mm}$ and the summer monsoon precipitation was $120.2 \mathrm{~mm}$. In 2001, the annual precipitation was $141.4 \mathrm{~mm}$ and the summer monsoon precipitation was 109.4. In 2008, the annual precipitation was 274.3 and the summer monsoon rainfall was 217.5.

When the experiment was established, there were no significant differences among the shrubs assigned to the treatments. In the second year after the exclosure cylinders were installed, there were no significant differences in green stem lengths between the stem lengths of the set-up year and the stem lengths in 2001 $\left(\mathrm{p}<0.67, \mathrm{~F}_{3,30}=0.40\right)$ (Figure 1). There were significant differences among the rabbit-rodent exclosed plants and the rabbit exclosed plants compared to plants available to all herbivores $\left(\mathrm{p}<0.0001, \mathrm{~F}_{3,30}=32.1\right)$. Plants available to all herbivores had shorter green stems than the exclosed plants. This pattern remained the same when the plants were re-measured in 2008 after the pasture was no longer grazed by cattle $\left(\mathrm{p}<0.0003, \mathrm{~F}_{3,30}=10.7\right)$. In 2008, green stem lengths of the plants exposed to all herbivores were essentially the same as those of $E$. torreyana stems on plants in the black grama grassland on the Armendariz Ranch, while the stems of plants protected from rodents and rabbits were longer than those reported by [6] (Figure 1).

When E. torreyana plant volumes were compared between the set-up and final year of measurements, there were significant differences between exclosed plants

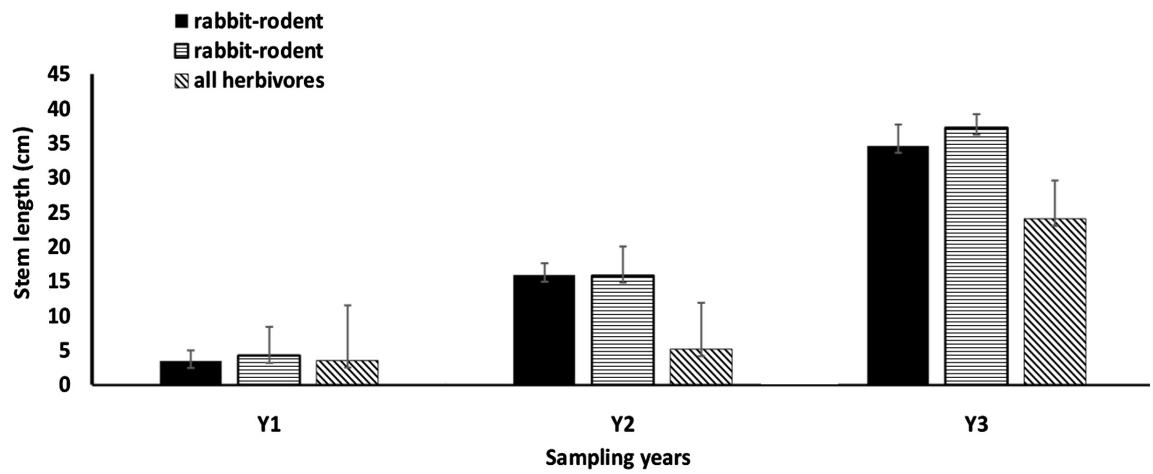

Figure 1. Comparison of photosynthetic stem lengths of Ephedra torreyana plants in rabbit-rodent exclosures, rabbit exclosures, and available to all herbivores. 
and plants available to all herbivores (Figure 2). There were no differences between the volume of plants when the experiment was set-up and the plants available to all herbivores, nine years after the experiment was set-up ( $\mathrm{p}<$ $\left.0.0001 ; F_{3,30}=64.46\right)$ a significant difference was observed. Exclosed plants were larger than those available to all herbivores, but since the pasture was no longer grazed by cattle, the herbivory experienced by $E$. torreyana was solely the effect of jackrabbits and cottontails (Figure 2). Herbivory by jackrabbits and desert cottontails after cattle were removed was essentially the same as before cattle were removed.

Since the shrub volume and stem lengths were measured in October, those measurements reflect the growth during the summer monsoon season. Most of the herbivory on E. torreyana occurs during the dry winter season. The summer monsoon rainfall during the time span of the experiment was sufficient for shrubs to produce new photosynthetic stems.

When the experiment was established, the pasture was grazed by cattle. However, when the plants were re-measured in 2008, the no cattle had been grazing the pasture for three years. The impact of herbivores on the $E$. torreyana before the cattle was removed from the pasture were most heavily impacted by rabbits or rabbits and rodents (Figure 2). However, there were no differences in the plots available to all herbivores, where the size of the E. torreyana in the exclosures available to all vertebrates is probably the result of the sparse vegetation of the tarbush shrubland that makes the E. torreyana apparent to most animals. $E$. torreyana shrubs surrounded by grass tussocks are largely hidden from jackrabbits and desert cottontails. In the desertified tarbush shrubland, the E. torreyana plants at the study site were exposed with more than $1 \mathrm{~m}$ of bare soil around the remnant shrubs and all had been heavily browsed when the experiment was set up. Grass tussocks were not present at the study site at the beginning or at the end of the experiment.

\section{Discussion}

Ephedra spp. are gymnosperms that produce seed cones, have scale-like leaves,

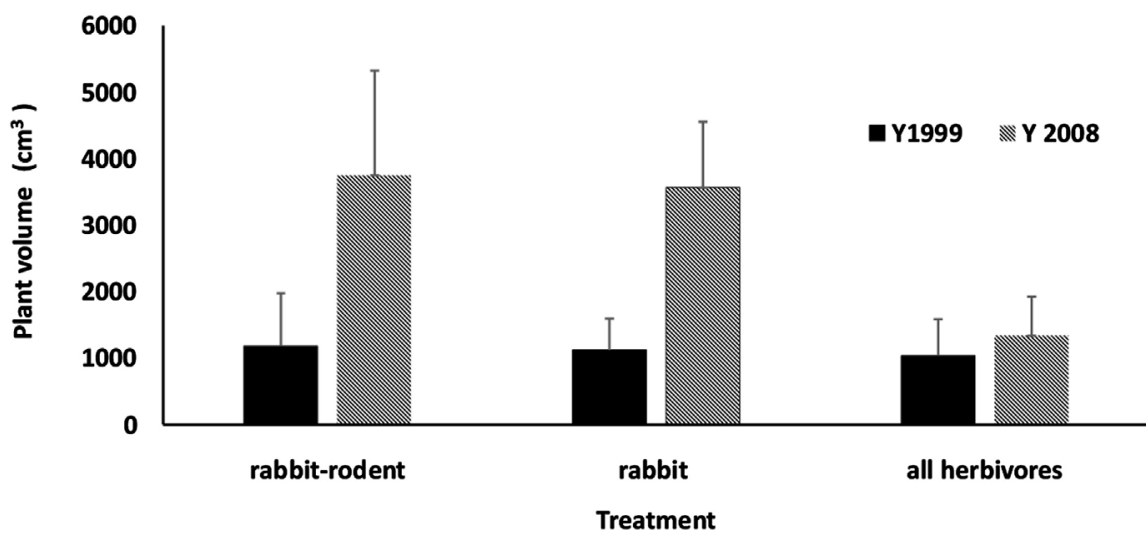

Figure 2. Comparison of Ephedra torreyana plant volumes when the experiment was set-up (1999) and three years after cattle were no longer grazed in the pasture. 
and photosynthetic stems. The photosynthetic stems are succulent, but most species are protected from herbivory by a complex of feeding deterrents that may include several related alkaloids: ephedrine and pseudoephedrines plus other toxic compounds [7]. However, not all species have similar suites of compounds that deter herbivory [8]. Such differences probably account for the apparent absence of vertebrate herbivory on Ephedra trifurca and the severe damage to Ephedra torreyana.

There are few reports on herbivory on Ephedra spp. There is one report of a herbivore that became extinct during the Pleistocene, the Shasta ground sloth, where Ephedra nevadensis accounted for $18 \%$ of its diet [9]. There is one study that reported damage from herbivory by livestock on Ephedra sinica plants. Loss of photosynthetic stems in the spring resulted in no regeneration of new stems one year after stem removal and during the next year the plants became smaller and produced few cones [10]. Other vertebrate herbivores that are known to feed on Ephedra spp. are brown hares (Lepus europaeus) that utilize Ephedra spp. primarily in winter [11] and the great gerbil (Rhombomys opimus) for which Ephedra przewalskiii accounted for $12 \%$ of the diet in the Gurbantoggut desert, Xinjiang, China [12]. It is probable that the brown hares and great gerbil utilize the evergreen Ephedra primarily as a source of water during periods of the year when there is an absence of succulent vegetation. Our study provides experimental evidence that domestic livestock, jackrabbits (Lepus californicus) and cottontail rabbits (Sylvilagus auduboni) reduce the re-growth of E. torreyana.

The most important finding of this study is that visual location of $E$. torreyana by herbivores is the most important factor resulting in the reduced photosynthetic stem production. When we studied the effects of fire on plants in a black grama (Bouteloua eriopoda), the only E. torreyana plants that were visible were shrubs that were left in the burned area [4]. The E. torreyana plants in the unburned areas were hidden by the larger tussocks of black grama grass and showed no signs of browsing by herbivores. There were jackrabbits (Lepus californica) and desert cottontails (Sylvilagus audubonit) living within the fenced enclosure but these animals did not browse on the E. torreyana that were surrounded by grass tussocks. If the low growing $E$. torreyana shrubs are not apparent to herbivores, they are not browsed. However, in the area where we conducted the study, there were no black grama tussocks in the area which had experienced loss of grasses and increased shrub cover [5]. When cattle were in the pasture where the study was set up, they ate many of the photosynthetic stems of E. torreyana and the two lagomorphs browsed the stems down to the woody stems or root crown.

Variation in densities of galls produced by Cecidomyiidae flies (Diptera) resulted from variation in soil water and inorganic nitrogen concentrations on a northern Chihuahuan Desert watershed [13]. Another invertebrate species that has been reported to utilize the bark of E. trifurca is the desert millipede, Orthoporus ornatus [14]. These few data suggest that the differences in chemical 
composition of the photosynthetic stems probably account for herbivory on some Ephedra spp. and the lack of herbivory on other species of Ephedra.

\section{Acknowledgements}

Dr. Graham I. H. Kerley assisted with the setup of the experiment. The study was supported in part by the International Arid Lands Consortium. Many thanks to Ms. Sharon Victor for her comments and great help in preparing the manuscript for publication.

\section{Conflicts of Interest}

The authors declare no conflicts of interest regarding the publication of this paper.

\section{References}

[1] Hollander, J.L., Vander Wall, S.B. and Baguley, J.G. (2010) Evolution of Seed Dispersal in North American Ephedra. Evolutionary Ecology, 24, 333-345.

https://doi.org/10.1007/s10682-009-9309-1

[2] Loera, I., Sosa, V. and Ickert-Bond, S.M. (2012) Diversification in North America Arid Lands: Niche Conservatism, Divergence and Expansion of Habitat Explain Speciation in the Genus Ephedra. Molecular Phylogenetics and Evolution, 65, 437-450. https://doi.org/10.1016/j.ympev.2012.06.025

[3] Whitford, W.G. (2002) Ecology of Desert Systems. Academic Press, London.

[4] Killgore, A., Jackson, E. and Whitford, W.G. (2009) Fire in Chihuahuan Desert Grassland: Short-Term Effects on Vegetation, Small Mammal Populations, and Faunal Pedoturbation. Journal of Arid Environments, 73, 1029-1034. https://doi.org/10.1016/j.jaridenv.2009.04.016

[5] Buffington, L.C. and Herbel, C.H. (1965) Vegetational Changes on a Semidesert Grassland Range from 1858-1963. Ecological Monographs, 35, 139-164. https://doi.org/10.2307/1948415

[6] Kerley, G.I.H., Whitford, W.G. and Kay, F.R. (1997) Mechanisms for the Keystone Status of Kangaroo rats: Graminivory Rather Than Granivory? Oecologia, 111, 422-428. https://doi.org/10.1007/s004420050254

[7] Chebouat, E., Gherraf, N., Dadamoussa, B., Chirite, A. and Zellagui, A. (2016) Chemical Composition of the Drichloromethane Extract of Ephedra alata Leaves and Flowers. Der Pharmacia Lettre, 8, 19-13.

[8] Long, C., Kakiuchi, N., Zhong, G. and Mikage, M. (2005) Survey on Resources of Ephedra Plants in Xinjiang. Biological and Pharmaceutical Bulletin, 28, 285-288. https://doi.org/10.1248/bpb.28.285

[9] Hansen, R.M. (1978) Shasta Ground Sloth Food Habits, Rampart Cave, Arizona. Paleobiology, 4, 302-319. https://doi.org/10.1017/S0094837300006011

[10] Mikage, M., Hong, H. and Cai, X. (2008) Studies of Ephedra Plants in Asia. Part 5. The Herbivory Damage to Ephedra Plants by Livestock. Journal of Traditional Medicines, 23, 108-111.

[11] Puig, S., Videla, F., Cona, M.I. and Monge, S.A. (2007) Diet of the Brown Hare (Lepus europaeus) and Food Availability in Northern Patagonia (Mendoza, Argentina). Mammalian Biology, 72, 240-250. 
https://doi.org/10.1016/j.mambio.2006.08.006

[12] Liu, W., Xu, W., Yang, W., Xu, F. and Qiao, H. (2012) Food Habits of the Great Gerbil (Rhombomysopimus) in the Southern Gubantunggut Desert, Xinjiang, China. Pakistan Journal of Zoology, 44, 931-936.

[13] Boecklen, W.J. and Hoffman, M.T. (1993) Sex-Biased Herbivory in Ephedra trifurca: The Importance of Sex-by-Environment Interactions. Oecologia, 96, 49-55. https://doi.org/10.1007/BF00318030

[14] Wooten Jr., R.C. and Crawford, C.S. (1975) Food, Ingestion Rates, and Assimilation in the Desert Millipede Orthorporusornatus (Girard) (Diplopoda). Oecologia, 20, 231-236. https://doi.org/10.1007/BF00347475 